Castellanos-Mejía, M.C., Herrera, J., Noguera-Urbano, E.A., Parra, E., \& Jiménez-Segura, L.F. (2021). Potential distribution in Colombia of the introduced fish Pangasianodon hypophthalmus (Siluriformes: Pangasiidae) and implications for endangered native fish. Revista de Biología Tropical, 69(2), 573-587. DOI 10.15517/rbt. v69i2.44223

DOI $10.15517 /$ rbt.v69i2.44223

\title{
Potential distribution in Colombia of the introduced fish Pangasianodon hypophthalmus (Siluriformes: Pangasiidae) and implications for endangered native fish
}

\author{
María C. Castellanos-Mejía ${ }^{1 *, 2}$ \\ Juliana Herrera ${ }^{1}$ \\ Elkin A. Noguera-Urbano ${ }^{3}$ \\ Edison Parra ${ }^{4}$ \\ Luz F. Jiménez-Segura ${ }^{1}$
}

1. Laboratorio de Ictiología, Instituto de Biología, Universidad de Antioquia, Medellín, Colombia; mcaste17nbk@gmail.com (*Correspondence), juliana.herrera.p@udea.edu.co,luz.jimenez@udea.edu.co

2. Departamento de Ciencias Biológicas, Escuela de Ciencias, Universidad EAFIT, Medellín, Colombia; mcastel7@eafit.edu.co

3. Instituto de Investigación de Recursos Biológicos, Alexander von Humboldt, Bogotá, Colombia; elkalexno@gmail.com

4. Grupo de Investigación en Limnología Básica y Experimental y Biológica y Taxonómica Marina, Instituto de biología, Universidad de Antioquia, Medellín, Colombia; edisonparra50@gmail.com

$$
\text { Received 15-X-2020. Corrected 05-IV-2021. Accepted 12-IV-2021. }
$$

\begin{abstract}
Introduction: One of the significant threats to aquatic ecosystems is introducing non-native species in natural environments. This represents one of the principal causes of biodiversity loss in the world. Pangasianodon hypophthalmus is an introduced species in Colombia that shares life characteristics and habitat with endangered native species, such as Ageneiosus pardalis, Sorubim cuspicaudus, and Pseudoplatystoma magdaleniatum. However, its distribution is little-known, and scientists have barely explored the effects on the native fauna. Objectives: To evaluate the $P$. hypophthalmus invasive potential in some of the Colombian basins, which drain into the Caribbean Sea. Methods: Using records available in various databases, we performed a niche conservatism analysis between the native and introduced records of $P$. hypophthalmus using the $\mathrm{R}$ package Ecospat. Subsequently, we modeled the potential invasion area of $P$. hypophthalmus and the distribution areas of three native species, performing ecological niche modeling (ENM) using the Maxent algorithm. Finally, we calculated a geographic niche overlap between the non-native and native species. Results: The Ecospat spatial analysis indicated that $P$. hypophthalmus retains some environmental niche attributes through space. For this reason, we can use ENM as an approximation to its range of distribution in the invaded area. Our results using ENM demonstrated that the four species analyzed prefer low and slightly rocky regions; therefore, the geographical overlap of the three native species' ecological niches and the introduced species exceed $80 \%$. Conclusions: There are adequate conditions in the study basins to fully establish the species $P$. hypophthalmus, representing a high risk for aquatic ecosystems and native ichthyofauna. Knowledge of the potential distribution areas is essential to implement control of the species.
\end{abstract}

Key words: niche models; freshwater; invasive species; migratory fish. 
Globalization through increased trade, transport, travel, and tourism will inevitably increase the intentional or accidental introduction of organisms to new environments (CABI, 2020) and is still steadily growing (Hulme et al., 2008; van Kleunen, Schlaepfer, Glaettli, \& Fischer, 2011). These introductions occasionally result in alien species' invasions (Lockwood, Hoopes, \& Marchetti, 2007). Invasive species have established populations outside their native distribution ranges and can spread and affect native ecosystems (Lockwood et al., 2007). These species can trigger ecological imbalances, trophic structure changes, native species displacements, biodiversity loss, genetic diversity reduction of native species, and non-native infectious agents' transport (Cassemiro, Bailly, da Graça, \& Agostinho, 2018; Hobbs, 2000). Thus, the introduction and later invasion of non-native species represent one of the leading causes of biodiversity loss in the world (Cattau, Martin, $\&$ Kitchens, 2010). The biggest problem associated with the introduced species is that they have been already established and extended when they are recognized as invasive, making it almost impossible to eliminate or control them (Sato et al., 2010). In some cases, native species declines often co-occur and in the same place as invasion by non-native species, leading many conservationists and researchers to believe that invasions and extinctions are closely linked (Gurevitch \& Padilla, 2004). For that reason, a prime objective of invasion biology is predicting which species are likely to become invaders and where they are likely to invade even before introduction outside their native range, which represents a goal of invasion ecologists (Fournier, Penone, Pennino, \& Courchamp, 2019).

The ecological niche modeling (ENM) use associations between environmental variables and occurrence locations of the species to predict the potential presence of the species in areas that have those ideal environmental conditions or that are appropriate for the survival of the species (Raxworthy et al., 2003; Raxworthy, Ingram, Rabibisoa, \& Pearson,
2007). This modeling has many applications, such as understanding species' ideal environmental conditions, predicting the existence of unknown species, inferring aspects of the biogeography of species, planning conservation areas, and as in this case, evaluating the potential areas of invasion of species (Peterson, 2006). In this way, ENM tools generates distribution maps of species, which are usefull for designing and leading strategies about control and mitigation of ecological problems generated by invasion processes, such as establishment, spread, and impact (Jiménez-Valverde et al., 2011). The invasion of species can be a highly predictable process if one knows the environmental conditions in the native range (Peterson, 2003; Jiménez-Valverde et al., 2011). The invasive species' geographic potential elaborated with ENM techniques is usually constructed assuming evolutionary conservatism in ecological niche characteristics. This means that species will follow the same set of ecological rules on invaded distributional areas as they do on their native distributional areas (Peterson, 2006); however, we should take this assumption with caution because both biotic and abiotic factors are different in native and non-native regions (Lockwood et al., 2007). In recent years, evidence that changes between the native and non-native niche exist in fish and other organisms have been found (Lauzeral et al., 2011). However, the ENM allows valid estimates of the geographical distribution of invasive species or their invasiveness (Yiwen, Bi Wei, \& Darren, 2016; Srivastava, Lafond, \& Griess, 2019).

Pangasianodon hypophthalmus (Sauvage, 1878) family Pangasiidae (Siluriformes) is native to the Mekong and Chao Phraya rivers basin in Southeast Asia. It carries out longdistance movements during hundreds of kilometers between ecosystems in high areas and spawning habitats. This species uses floodplain lands to feed and breed (FAO, 2010; IAvH, s.f.; Tarkan et al., 2020). A female in suitable conditions can produce around 100000 eggs per kilogram in each oviposition, and its demersal embryos suggest some parental care (e.g., nests 
on a hard substrate). These hatch in 24 hours, and the larvae drift in favor of the floods, searching for growth zones within flooded areas. Its larvae have an omnivorous diet that includes algae, seeds, crustaceans, zooplankton, and fish (Van Zalinge, Lieng, Ngor, Heng, \& Valbo-Jørgensen, 2002). As an adult, it is carnivorous and even cannibalistic. The species has been reported as a predator of native species in some places of Asia (Pallewatta, Reaser, \& Gutierrez, 2003).

Combining the aforementioned biological characteristics and the escape and introduction of exemplary species in places other than their natural distribution justify their classification as an invasive species or a potentially invasive species (Gutiérrez, Lasso, Baptiste, SánchezDuarte, \& Díaz, 2012; Garcia et al., 2018). Its broad food spectrum, the ease with which it gains weight, and its fast growth have made it possible to introduce this species with productive purposes in different countries such as Cuba, Chile, Colombia, Guatemala, México, the United States, Indonesia, India, Turkey, Puerto Rico, and The Dominican Republican (IAvH, s.f.). However, fish farming of $P$. hypophthalmus presents problems such as the spreading of pathogens that are difficult to control (Bigarré et al., 2009; Lakra \& Singh, 2010; Mitra, Bandyopadhyay, Gong, Goswami, \& Bhowmik, 2013), and increasing cost for its production (Lakra \& Singh, 2010; Singh \& Lakra, 2011).

In Colombia, the species started to be used as an ornamental fish, and in 2008 its meat began to be imported for national consumption in frozen fillets. Currently, it is sold in fresh fish marketplaces (Valderrama, Mojica, Villalba, \& Avila, 2016). Pangasianodon hypophthalmus farming has been reported in at least five states of the country: Valle del Cauca, Cauca, Huila, Meta and Santander (Gutiérrez et al., 2012). Since 2015, live specimens have been captured by fishermen in the aquatic ecosystems of Magdalena River, in floodplains of the lower zone, and in main riverbeds and tributary rivers (Valderrama et al., 2016). However, the distribution of this species in
Colombia is little-known, and scientists have barely explored the effects on the native fauna. In the Caribbean sub-basins such as the Magdalena, Atrato, Sinú, and Catatumbo rivers, there are other siluriform species that, like $P$. hypophthalmus, carry out long-distance migrations between small tributaries and floodplains, have carnivorous habits, and use floodplains as breeding and growth areas. Among these species are Pseudoplatystoma magdaleniatum, Sorubim cuspicaudus, and Ageneiosus pardalis, which are of high importance for commercial and artisanal fishing and are under a critical conservation status (P. magdaleniatum) and vulnerable (S. cuspicaudus and A. pardalis) (Mojica, Usma, Álvarez-León, \& Lasso, 2012). In these sub-basins, only the Magdalena river basin contributes $70 \%$ of the gross domestic product, and $80 \%$ of the population lives in its territory (The Nature Conservancy, Fundación Alma, Fundación Humedales, \& AUNAP, 2016). As a result, this basin presents several environmental conflicts in its aquatic ecosystems (Barletta et al., 2010; Galvis \& Mojica, 2007; Jiménez-Segura et al., 2016). Although habitat destruction and human pressures are major causes of this conservation status, potential competitive interactions could occur with introduced species, which might worsen the conservation state of native species. For this reason, our objective was to evaluate the invasive potential of $P$. hypophthalmus in some of the basins of the Caribbean Sea watershed (1) making a comparison between the native niche and the niche of introduction in the Caribe watershed, (2) transferring the ENM calibrated with the native area of this species in Colombia to calculate the possible area of invasion and (3) comparing the geographical distribution of $P$. hypophthalmus with the distribution of three native species (P. magdaleniatum, S. cuspicaudus, and A. pardalis) present in rivers of the Caribbean basin.

\section{MATERIALS AND METHODS}

Study area: We focused on 5 sub-basins of Caribbean Basin: Magdalena-Cauca, Atrato, 
Sinú, and Catatumbo. In the Caribbean basin located North of the Andes, 326 fish species were reported, from which $66 \%$ were endemic (DoNascimiento et al., 2017). Of these endemic species, 35 were reported based on specimens captured by artisanal fishermen (Jiménez-Segura, Gutierrez, Ajiaco-Martínez, \& Lasso, 2020a); 19 of them have migratory behaviors and move seasonally among low areas and the Magdalena, Atrato, Sinú and Ranchería river tributaries (Jiménez-Segura et al., 2016; López-Casas, Jiménez-Segura, Agostinho, \& Pérez, 2016).

Data of presence: The georeferenced records of the wildlife of $P$. hypophthalmus both in the native and introduced ranges and of P. magdaleniatum, S. cuspicaudus, and A. pardalis were compiled from the review of scientific articles, reports of field observations, and databases available online as Freshwater Biodiversity Data Portal (Biofresh, 2012), the Global Biodiversity Information Facility (GBIF, 2019; GBIF, 2020a; GBIF, 2020b; GBIF, 2020c) and the platform InvBasa through SIB Colombia (InvBasa UN, 2020; SiB Colombia, 2020). Databases were reviewed and curated, applying verification procedures of duplicate records or taxonomic uncertainty (Chapman, 2005). Records that did not coincide with water sources were relocated to the nearest pixel (Domisch, Wilson, \& Jetz, 2016).

Environmental data: We selected 70 environmental variables from the freshwater systems that have a relationship with the analyzed species' biology (for example, flow, substrate type, and surrounding vegetation (Nori \& Rojas-Soto, 2019). The variables are available on the EarthEnv website (Domisch, Amatulli, \& Jetz, 2015) and have a $1 \mathrm{~km}$ resolution global coverage. This dataset includes earth covers, climatic and topographic variables, and soil characteristics. Besides, we included a flow layer average for the periods 1960-2015 (Barbarossa et al., 2018), which is available globally at a resolution of $1 \mathrm{~km}$ (Digital Appendix 1).
The accessible area or mobility (M) can condition the models' evaluation methods and their accuracy (Barve et al., 2011). Therefore, we defined each species-area by making an intersection between each species' presence records with a map of watersheds HydroBASINS 1.0 Level 6 (Lehner \& Grill, 2013). To evaluate the range of possible invasion of $P$. hypophthalmus in Colombia, we selected the largest $\mathrm{M}$ within the native species (A. pardalis) (Digital Appendix 2). All variables were trimmed with the $\mathrm{M}$ defined using the raster package (Hijmans et al., 2015) in the program R (R Core Team, 2014).

Comparison between the native and the introduction niche of $P$. hypophthalmus: The niche comparisons were made by following Broennimann et al. (2012) proposal,which consisted of getting values of niche similarity in the environmental space using Schoener's D similarity metric (Warren, Glor, \& Turelli, 2008). This technique uses the first two axes of principal component analysis (PCA) that reduce the 71 environmental variables to know the environmental conditions occupied by $P$. hypophthalmus. We calculated the native niche stability proportion observed in the exotic niche and the expansion of the species' new environments in the non-native niche. Subsequently, we tested for niche similarity by assessing random changes of the niches within available conditions in the study area, i.e., assessing if the niche of the species is more similar than expected by chance under a specific null model (Warren et al., 2008; Warren, Glor, \& Turelli, 2010). We made all analyses using available tools in the Ecospat package (Di Cola et al., 2017) in the software R (R Core Team, 2014).

Modeling and projection of the ecological niche: We built the ENM for each species using 71 environmental variables and the Maximum Entropy algorithm (Maxent) (Phillips, Dudík, \& Schapire, 2004; Phillips, Anderson, \& Schapire, 2006) through the ENMeval package (Muscarella et al., 2014) in the R program (R Core Team, 2014). We selected Maxent 
because of its capability to mitigate redundant variables' contributions (Elith et al., 2011; Feng, Park, Liang, Pandey, \& Papes, 2019). Also, the algorithm has shown to remain stable both in the precision of the prediction and the total predicted area present using different categories of sample sizes (Phillips \& Dudík, 2008; Wisz et al., 2008; West, Kumar, Brown, Stohlgren, \& Bromberg, 2016).

In the construction of the P. hypophthalmus model, we used the Jackknife method (Pearson, Raxworthy, Nakamura, \& Peterson, 2007) with 31 folds given the low number of obtained records, while for native species, we used the random kfold method, 10000 background points by default, and the combination of feature classes (Linear, Quadratic, Linear-Quadratic, Hinge, Linear-QuadraticHinge) with ten regularization values ( 0.5 to 5 , each 0.5 ). The best model for each species was selected, bearing in mind that the lowest $\triangle \mathrm{AIC}$ (the best models taking into account the smallest number of parameters, Muscarella et al., 2014) and the logistic output were used for all models. Finally, we converted the suitability map to binary map using the 10P cut-off threshold value (tenth percentile) for the P. hypophthalmus and MTP (minimal training presence) threshold value for the native species.

Ecological niche overlap of native species with non-native species: We estimated geographical overlap between the $P$. hypophthalmus and each native species summing their binary maps of distribution in QGIS software (QGIS, 2020). Then, we calculated the number of pixels corresponding to the spatial overlap among areas of predicted distribution of each species.

\section{RESULTS}

Data of presence: We analyzed a total of 31 records for the native area of $P$. hypophthal$m u s$ and 25 in the non-native area, 57 records for P. magdaleniatum, 93 for S. cuspicaudus, and 159 for A. pardalis (Digital Appendix 3, Digital Appendix 4, Digital Appendix 5, Digital Appendix 6).

Comparison between the native niche and introduction niche of $P$. hypophthalmus: For the comparisons between the introduction and the native niche, we obtained PCA that explains $53.36 \%$ of the variance, with a Schoener's D value of 0.125 , an expansion of $24 \%$, and stability of $76 \%$ (Fig. 1A). On the other hand, similarity tests show that native and introduced range niches are more similar to what is expected by chance $(\mathrm{P}=0.047$; Fig. 1B). Therefore, the niche of $P$. hypophthalmus has significantly conserved non-native area.

Ecological niche modeling: $P$. hypophthalmus is widely distributed in the Asian tropical region in Laos, Thailand, Vietnam and Cambodia (Fig. 2A). The ecological niche model made for its natural distribution zone gives a probability value of the area under the curve (AUC) of 0.94, indicating that the model had a good performance. The selected variables provided a satisfactory prediction of the species distribution (Table 1).

TABLE 1

Selected model for each of the species

\begin{tabular}{lccccccc}
\multicolumn{1}{c}{ Species } & Feature classes & $\begin{array}{c}\text { Regularization } \\
\text { multiplier }\end{array}$ & AICc & AUCtrain & AUCtest & $\begin{array}{c}\text { Number of } \\
\text { parameters }\end{array}$ & $\begin{array}{c}\text { Cut-off } \\
\text { threshold }\end{array}$ \\
P. hypophthalmus & L & 4.5 & 619.92 & 0.9541 & 0.9426 & 9 & $10 \mathrm{P}$ \\
P. magdaleniatum & $\mathrm{L}$ & 2.5 & 1048.7 & 0.9445 & 0.9001 & 18 & MTP \\
S. cuspicaudus & $\mathrm{H}$ & 3.5 & 1765.6 & 0.9298 & 0.8989 & 24 & MTP \\
A. pardalis & $\mathrm{LQH}$ & 5 & 2842.3 & 0.0495 & 0.9389 & 24 & MTP \\
\hline
\end{tabular}

$\mathrm{L}=$ Linear, $\mathrm{H}=$ Hinge, $\mathrm{LQH}=$ Linear-Quadratic-Hinge. 

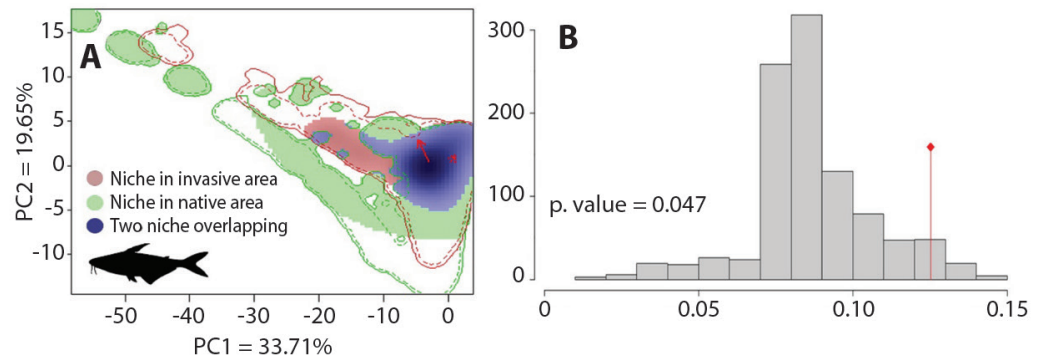

Fig. 1. Comparisons of the native and introduced niche of P. hypophthalmus. A. Test's PCA results proposed by Broennimann et al. (2012). The shadow in the blue zone represents the species' density, while the continuous and dotted red and green contours represent $100 \%$ and $25 \%$ respectively of the available environment in both zones. B. Niche similarity index histograms, the red bar the value of Schoener's D. The histogram corresponds to the niche similarity of the non-native niche in the Colombian region.

Seven variables contributed to obtaining the final model and predicting the geographic areas with environmental suitability characteristics for $P$. hypophthalmus in the basin of Mekong and Chao Phraya rivers (Digital Appendix 7). Among these variables, the first one is the elevation (elevation_01) and was the most influential factor in the model, followed by the percentage of thick fragments in the soil (fraction $>0.2 \mathrm{~mm}$; soil_minimum_06) and the minimum percentage of the substrate type ( $\mathrm{R}$ horizon or bedrock; soil_minimum_10). Therefore, based on the response curves and geographic representation (Digital Appendix 8 ), we identified that the species is located in lower areas of the basin where the composition of the riverbed is mainly small fragments (sands, clays, silts). Those conditions represent a total of $19938 \mathrm{~km}^{2}$ of the basins of its native distribution. When we projected the model to
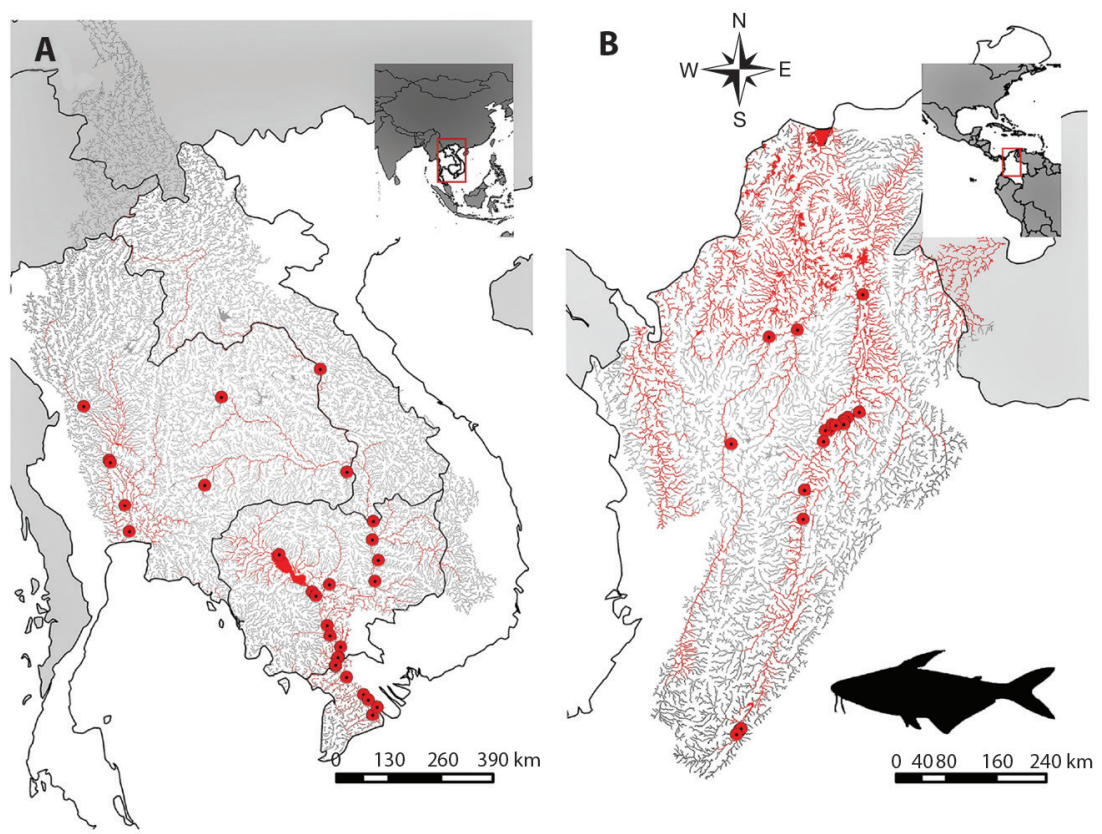

Fig. 2. Potential distribution of $P$. hypophthalmus represented in red lines. A. Its native area in Laos, Thailand, Vietnam and Cambodia. B. Its non-native area in Colombia. The red dots represent occurrences. 
Colombia (Fig. 2B), we found that the species can cover a potential area of $27801 \mathrm{~km}^{2}$ of the Magdalena, Cauca, Atrato, and Catatumbo river basins, representing $48.26 \%$ of the total extension of water bodies in the area $\left(57597 \mathrm{~km}^{2}\right)$.

In native tree ecological niche models for native species, all AUC test values are greater than 0.898 , indicating good performance (Table 1). The variable elevation (elevation_01) made the most significant contribution to the three models, placing the three species in lowland areas. The $\mathrm{R}$ horizon's minimum percentage was the second most important variable for the S. cuspicaudus and P. magdaleniatum models, indicating that these species prefer areas with low percentages of rocky material or bedrock. Additionaly, the second most important variable was the coldest month in the case of the species $A$. pardalis. This indicates that higher values fo temperature $\left(\sim 20^{\circ} \mathrm{C}\right)$ favored the presence of the species; however, a low percentage of $\mathrm{R}$ horizon values also influenced the final model (Digital Appendix 9, Digital Appendix 10, Digital Appendix 11, Digital Appendix 12, Digital Appendix 13, Digital Appendix 14).

Ecological niche overlap of native species with non-native species: The geographical overlap analysis shows that the $P$. hypophthalmus distribution area in Colombia covers 91.79 $\%$ of the suitable environmental zones of the A. pardalis; this means that $P$. hypophthalmus overlaps $17400 \mathrm{~km}^{2}$ of the native species' distribution (Fig. 3A, Fig. 3D). In the case of S. cuspicaudus species, we found an $82.17 \%$ overlap where both species overlap in 20045 $\mathrm{km}^{2}$ (Fig. 3B, Fig. 3E), while for P. magdaleniatum there is an overlap of $91.72 \%$, which is equivalent to $10342 \mathrm{~km}^{2}$ (Fig. 3C, Fig. 3F).

\section{DISCUSSION}

Our results suggest a climatic niche conservatism in P. hypophthalmus. It shows that this species is in similar climatic characteristics in both their native and invasive ranges.
We also found that around $45 \%$ of our study area is susceptible to invasion. These results have important implications because they are the first demonstration of a possible invasion range of $P$. hypophthalmus, and the risk that they represent for other species with their same behavior.

Environmental Niche Models can provide a realistic proxy about the geographic range of a fish species, and they can be used for several purposes, including conservation action (Valencia-Rodríguez et al., 2021). In biological invasions, niche models and their transfers to non-native geographical zones require caution in their interpretation (Owens et al., 2013). Thus, a fundamental assumption for allowing geographic predictability between native distribution areas and invaded areas is the niche conservatism analysis of the introduced species. According to this assumption, the species usually conserves its ancestral niche in the invaded regions (Wiens \& Graham, 2005; Broennimann et al., 2007; Liu, Wolter, Xian, \& Jeschke, 2020). On the one hand, we found that $P$. hypophthalmus shows conservatism of ecological niche; for that reason, we could transfer the calibrated ENM from the native to the non-native area with a confidence approximation of the possible invasion in our study area. On the other hand, we obtained an expansion estimation of the niche that could indicate that $P$. hypophthalmus occupies new habitats in Colombia that are not represented in its native range. These results would imply that the P. hypophthalmus fundamental niche is broader than the niche represented in their native area. By contrast the expansion detected may also be explained by the low numbers of records in its native zone, which would lead to incomplete representation of the niche; however, the records used to train the P. hypophthalmus model in its native area correspond with the known distribution area of the species (FAO, 2010).

The selection of environmental predictors is a fundamental step to produce ENMs; if predictors are biologically informative, they represent more realistic species-environment 

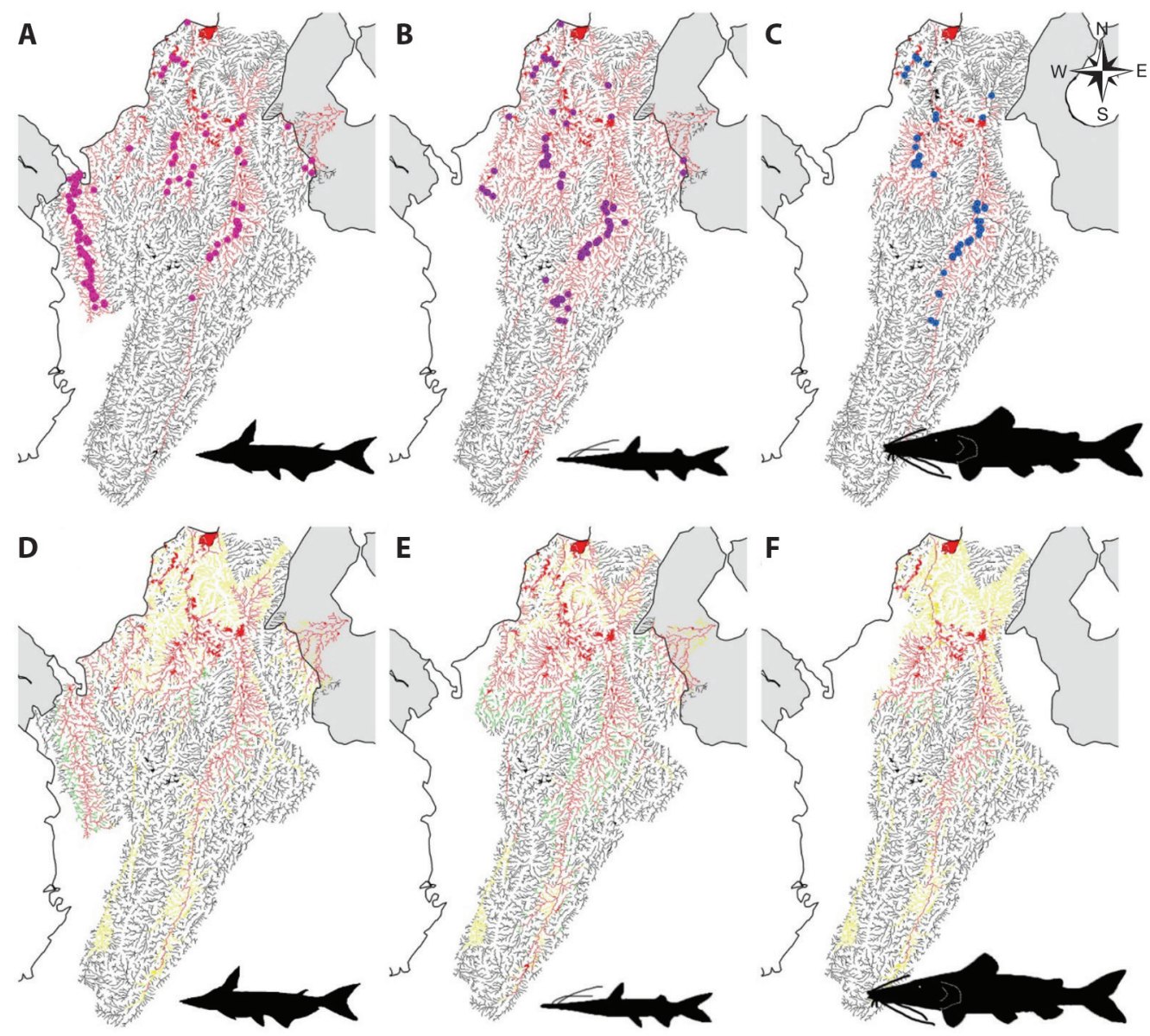

Fig. 3. Potential distribution of three native species represented in red lines: A. A. pardalis. B. S. cuspicaudus. C. $P$. magdaleniatum. And their areas of distribution overlapping the distribution of P. hypophthalmus: D. A. pardalis. E. $S$. cuspicaudus. F. P. magdaleniatum. The red color symbolizes the overlap between the native and non-native species; the yellow color is the area for the P. hypophthalmus species, and the green color the range of the native species.

relationships (Parra, Graham, \& Freile, 2004), and thus models are projected more accurately into novel environments. It has even been suggested that elevation, slope, precipitation, soil features, temperature, and vegetation, define the type of aquatic ecosystems (Baron et al., 2003). Therefore the variables selected to build our models estimate important environmental preferences of the four species analyzed. Altitude takes on particular importance because freshwater species are confined to water bodies with specific characteristics. The elevation is a direct conditioner of characteristics, such as flow, substrate, or vegetation (Nori \& Rojas-Soto, 2019). Notably, basins with lower altitude values correspond with high values of suitability predictions, which represents topographic variability that facilitate migration and / or prevent dispersal process within the hydrographic network (Castillo-Torres, MartínezMeyer, Córdova-Tapia, \& Zambrano, 2017). Another important environmental variable that explained the potential distribution of the four species was the percentage of coarse fragments in the river bed. This variable is a factor that determines the nutritional and chemical 
conditions of the rivers, and it characterizes the structure and dynamics of the aquatic habitat (Baron et al., 2003). Followed by this, variables related to temperature, such as the minimum temperature of the coldest month, influenced the models, being associated directly with the organisms' fitness and, by extension, determines the place where the species are distributed and how their community varies. Also, another variable selected was the precipitation seasonality which determines the flow pattern of rivers, lakes, and wetlands, which influence a large part of the habitat of freshwater species (Baron et al., 2003).

The presence of $P$. hypophthalmus in Colombia has been previously recorded from field observations (Valderrama et al., 2016). The individuals of $P$. hypophthalmus free in natural environments may be either by accidental escape from aquaculture or direct introductions from sport fishers or aquarists (Gutiérrez et al., 2012; Lasso et al., 2020). Consequently, in this study, the ENM allowed the identification of new areas suitable for the colonization of this species. The models indicated that the species' niche conditions are widely represented in the Colombian inter Andean valleys. It corresponds with low areas with sediments and sedimentary rocks (fragments such as sand, clay, silt, and consolidations of said fragments, respectively; Jaramillo, 2002). The proposed models indicate that the colonization of $P$. hypophthalmus in Colombia is possible. Its survival is confirmed by present records of P. hypophthalmus in Magdalena-Cauca, Sinú, Atrato, San Jorge, Cesar, and Catatumbo rivers basins. The spread and colonization of the aquatic ecosystems in Colombian basins by the $P$. hypophthalmus could be possible because the species has a high tolerance to changes in environmental conditions, mainly the resistance to low oxygen levels, salinity, pH changes, temperature, and turbidity fluctuations (Singh \& Lakra, 2011; Faruk, Patwary, \& Hasan 2012; Garcia et al., 2018; Islam, Uddin, Uddin, \& Shahjahan et al., 2019).

Pangasianoson hypophthalmus is a species that is easy to farm and popular among aquaculturists due to its resistance to water quality variations, fast growth, good survival rates, and economically attractive market size (Ali, Haque, \& Belton, 2013; Islam et al., 2019). Given this scenario and its invasive potential, authorities in countries such as Mexico do not allow or encourage the introduction and cultivation in their territories (Mendoza-Alfaro, Luna-Peña, \& Arias-Gámez, 2013; Delegación SADER Tamaulipas, 2017). Pangasianodon hypophthalmus has a great capacity for displacement due to its migratory nature and high fecundity. How we illustrate P. hypophthalmus presents life history characteristics similar to the native species analyzed here (MaldonadoOcampo et al., 2005; Jiménez-Segura, Palacio, \& López, 2009; Jiménez-Segura, Palacio, \& Leite, 2010; Jiménez-Segura et al., 2020b). These assessments of species' life features can offer rigorous scientific support for rapid classification of extinction or invasion risks and efforts to prevent invasion because of determining which species and sources of emerging invaders are worthy of scrutiny, more attention to management or policies must be applied (Liu, Comte, \& Olden, 2017). Comparing the $P$. hypophthalmus niche with the native species indicates that the four species share environmental conditions that spatially converge in the evaluated basins' lower and middle zones as high-water temperature and substrates with a high percentage of small fragments. (e.g. silts, clays). P. hypophthalmus is distributed almost entirely in the available space presented by the three native species, even though the modeled distribution range of $P$. hypophthalmus in Colombia is underestimated. Its convergence could trigger competition for space and food, and this species can even become a predator of juvenile and adult organisms of other species of fish consumed by native species (Gutiérrez et al., 2012; Raman et al., 2013). Competition and predation would cause mortality in native species and could even affect recruitment, and the result of this situation would be reductions in the genetic diversity of the native species (Raman et al., 2013). 
The finding of conserved climatic niche for invasive species has major implications for predicting future invasion risks. Because it permits a model transferability using niche models. This kind of study represents a costeffective strategy focused on identifyinging climatic conditions occupied in their native range but (not yet) colonized in their introduced range (Liu et al., 2020). We identify that $P$ hypophthalmus present a niche conservatism, and for that reason we identify areas with a high risk of being invaded. That is why we call on environmental authorities because it is important to develop short-term actions to avoid this species' dispersal. In this case, it is necessary to control its cultivation and use in aquariums. Although they may seem drastic measures, they should be considered by the Colombia's environmental and fisheries authorities. Posing that the legalization of the use of the species is the only way to control its current illegal exploitation is not an appropriate justification since the control measures for fish farmers and aquarists have historically been non very effective. Eradication through hunting and the control prohibition of its eventual cultivation directly in rivers must be accompanied by educational programs to help consumers understand the impact non-native species have on aquatic biodiversity, and to encourage fish farmers to use good practices to reduce the impact of their activities on natural aquatic environments; also, invest more resources in research for developing fish culture with native species. This is an environmental decision; the precautionary principle should always prevail, in the absence of more robust information on the invasive capacity of $P$. hypophthalmus in Colombia's river networks and on its real effect on a highly endemic aquatic biodiversity.

Ethical statement: authors declare that they all agree with this publication and made significant contributions; that there is no conflict of interest of any kind; and that we followed all pertinent ethical and legal procedures and requirements. All financial sources are fully and clearly stated in the acknowledgements section. A signed document has been filed in the journal archives.

\section{ACKNOWLEDGMENTS}

We thank Juan Luis Parra and Daniel Valencia for their support, suggestions and discussions. To the Humboldt Institute, InvBasa, Margarita Roa, Claudia Castellanos, and fishermen from Magdalena river basin for facilitating the systematization and compilation of the species presence in Colombia. To María Piedad Baptiste and Jose Manuel Ochoa from the Humboldt Institude for facilitating this collaboration between the University of Antioquia and Humboldt institutions. To Wyatt Maddenson and Carolina Soto for English grammar support, and finally, we would like to thank our reviewers and Octavio Rojas for improving our manuscript.

\section{RESUMEN}

\author{
Distribución potencial en Colombia del pez \\ introducido Pangasianodon hypophthalmus \\ (Siluriformes: Pangasiidae) e implicaciones para \\ los peces nativos en peligro de extinción
}

Introducción: Una de las amenazas importantes para los ecosistemas acuáticos es la introducción de las especies no nativas en ambientes naturales. Esto representa una de las principales causas de pérdida de biodiversidad en el mundo. Pangasianodon hypophthalmus es una especie introducida en Colombia que comparte características de vida y hábitat con especies nativas en peligro de extinción como: Ageneiosus pardalis, Sorubim cuspicaudus y Pseudoplatystoma magdaleniatum. Sin embargo, poco se conoce de su distribución y los efectos en la fauna nativa han sido poco explorados. Objetivo: Evaluar el potencial invasivo de $P$. hypophthalmus en algunas de las cuencas colombianas que desembocan en el Mar Caribe. Métodos: Utilizando registros disponibles en varias bases de datos, realizamos un análisis de conservadurismo de nicho entre los registros nativos e introducidos de $P$. hypophthalmus usando el paquete de R Ecospat. Posteriormente, modelamos el área potencial de invasión de $P$. hypophthalmus y las áreas de distribución de tres especies nativas realizando modelos de nicho ecológico (MNE) utilizando el algoritmo de Maxent. Finalmente, calculamos una superposición de nicho geográfico entre las especies nativas y no nativas. Resultados: El análisis espacial de Ecospat indica que P. hypophthalmus conserva algunos atributos del nicho 
ambiental a través del espacio. Por esta razón, podemos usar los MNE como una aproximación a su rango de distribución en el área invadida. Nuestros resultados usando MNE demostraron que las cuatro especies analizadas prefieren regiones bajas y ligeramente rocosas; por ello, la superposición geográfica de los nichos ecológicos de las tres especies nativas y la especie introducidas superan el $80 \%$. Conclusiones: Existen condiciones adecuadas en las cuencas de estudio para el establecimiento completo de la especie $P$. hypophthalmus, lo que representa un alto riesgo para los ecosistemas acuáticos y la ictiofauna nativa. El conocimiento de las áreas de distribución potencial es fundamental para implementar controles sobre la especie.

Palabras clave: modelos de nicho; agua dulce; especies invasoras; peces migratorios.

\section{REFERENCES}

Ali, H., Haque, M.M., \& Belton, B. (2013). Striped catfish (Pangasianodon hypophthalmus, Sauvage, 1878) aquaculture in Bangladesh: An overview. Aquaculture Research, 44(6), 950-965. DOI: 10.1111/j.1365-2109.2012.03101.x

Barbarossa, V., Huijbregts, M.A.J., Beusen, A.H.W., Beck, H.E., King, H., \& Schipper, A.M. (2018). Erratum: FLO1K, global maps of mean, maximum and minimum annual streamflow at $1 \mathrm{~km}$ resolution from 1960 through 2015. Scientific Data, 5(1), 180078. DOI: 10.1038/sdata.2018.78

Barletta, M., Jaureguizar, A.J., Baigun, C., Fontoura, N.F., Agostinho, A.A., Almeida-Val, V.M.F., ... Correa, M.F. (2010). Fish and aquatic habitat conservation in South America: a continental overview with emphasis on Neotropical systems. Journal of Fish Biology, 76, 2118-2176.

Baron, J.S., Poff, N.L., Angermeier, P.L., Dahm, C.N., Gleick, P.H., Hairston Jr, N.G., ... Steinman, A.D. (2003). Ecosistemas de agua dulce sustentables (Sustaining healthy freshwater ecosystems). Topicos en Ecologia, 10, 1-15.

Barve, N., Barve, V., Jiménez-Valverde, A., Lira-Noriega, A., Maher, S.P., Peterson, A.T., ... Villalobos, F. (2011). The crucial role of the accessible area in ecological niche modeling and species distribution modeling. Ecological Modelling, 222(11), 1810 1819. DOI: 10.1016/j.ecolmodel.2011.02.011

Bigarré, L., Cabon, J., Baud, M., Heimann, M., Body, A., Lieffrig, F., \& Castric, J. (2009). Outbreak of betanodavirus infection in tilapia, Oreochromis niloticus (L.), in fresh water. Journal of Fish Diseases, 32(8), 667-673. DOI: 10.1111/j.1365-2761.2009.01037.x

Biofresh. (2012). Pangasianodon hypophthalmus Sauvage, 1878. Freshwater Bidiversity Data Portal [Database]. Retrieved from http://data.freshwaterbiodiversity.eu
Broennimann, O., Fitzpatrick, M.C., Pearman, P.B., Petitpierre, B., Pellissier, L., Yoccoz, N.G., ...Guisan, A. (2012). Measuring ecological niche overlap from occurrence and spatial environmental data. Global Ecology and Biogeography, 21(4), 481-497. DOI: 10.1111/j.1466-8238.2011.00698.x

Broennimann, O., Treier, U.A., Müller-Schärer, H., Thuiller, W., Peterson, A.T., \& Guisan, A. (2007). Evidence of climatic niche shift during biological invasion. Ecology Letters, 10(8), 701-709. DOI: 10.1111/j.1461-0248.2007.01060.x

CABI (Centre for Agricultural Bioscience International). (2020). Invasive Species Compendium. Wallingford, UK: CAB International. Retrieved from http://www. cabi.org/isc

Cassemiro, F.A.S., Bailly, D., da Graça, W.J., \& Agostinho, A.A. (2018). The invasive potential of tilapias (Osteichthyes, Cichlidae) in the Americas. Hydrobiologia, 817(1), 133-154. DOI: 10.1007/s10750-017-3471-1

Castillo-Torres, P.A., Martínez-Meyer, E., Córdova-Tapia, F., \& Zambrano, L. (2017). Potential distribution of native freshwater fish in Tabasco, Mexico. Revista Mexicana de Biodiversidad, 88(2), 415-424. DOI: 10.1016/j.rmb.2017.03.001

Cattau, C.E., Martin, J., \& Kitchens, W.M. (2010). Effects of an exotic prey species on a native specialist: Example of the snail kite. Biological Conservation, 143(2), 513-520. DOI: 10.1016/j.biocon.2009.11.022

Chapman, A. (2005). Principles and Methods of Data Cleaning: Primary Species and Species-Occurrence Data, version 1.0. Report for the Global Biodiversity Information Facility, Copenhagen. Retrieved from https://www.gbif.org/document/80528

Delegación SADER Tamaulipas. (29 Septiembre, 2017). Prohíben introducción y cultivo de basa en México. [Web blog message]. Recuperado de https:// www.gob.mx/agricultura\% 7Ctamaulipas/articulos/ prohiben-introduccion-y-cultivo-de-basa-en-mexico

Di Cola, V., Broennimann, O., Petitpierre, B., Breiner, F.T., D’Amen, M., Randin, C., ... Guisan, A. (2017). ecospat: an R package to support spatial analyses and modeling of species niches and distributions. Ecography, 40(6), 774-787. DOI: 10.1111/ecog.02671

Domisch, S., Amatulli, G., \& Jetz, W. (2015). Near-global freshwater-specific environmental variables for biodiversity analyses in $1 \mathrm{~km}$ resolution. Scientific Data, 2(1), 1-13. DOI: $10.1038 /$ sdata.2015.73

Domisch, S., Wilson, A.M., \& Jetz, W. (2016). Model-based integration of observed and expert-based information for assessing the geographic and environmental distribution of freshwater species. Ecography, 39(11), 1078-1088. DOI: 10.1111/ecog.01925 
DoNascimiento, C., Herrera-Collazos, E.E., Herrera-R., G.A., Ortega-Lara, A., Villa-Navarro, F.A., Oviedo, J.S.U., \& Maldonado-Ocampo, J.A. (2017). Checklist of the freshwater fishes of Colombia: a Darwin Core alternative to the updating problem. ZooKeys, (708), 25-138.

Elith, J., Phillips, S.J., Hastie, T., Dudík, M., Chee, Y.E., \& Yates, C.J. (2011). A statistical explanation of MaxEnt for ecologists. Diversity and Distributions, 17(1), 43-57. DOI: $10.1111 / \mathrm{j} .1472-4642.2010 .00725 . x$

FAO (Food and Agriculture Organization). (2010). Pangasius hypophthalmus (Sauvage 1878). Cultured Aquatic Species Information Programme. Retrieved from http://www.fao.org/fishery/culturedspecies/ Pangasius_hypophthalmus/en

Faruk, M.A.R., Patwary, Z.P., \& Hasan, M.M. (2012). Clinical and histopathological investigations in exotic catfish Pangasianodon hypophthalmus (Sauvage, 1878) under culture condition. Indian Journal of Fisheries, 59(4), 183-185.

Feng, X., Park, D.S., Liang, Y., Pandey, R., \& Papeş, M. (2019). Collinearity in ecological niche modeling: Confusions and challenges. Ecology and Evolution, 9(18), 10365-10376. DOI: 10.1002/ece3.5555

Fournier, A., Penone, C., Pennino, M.G., \& Courchamp, F. (2019). Predicting future invaders and future invasions. Proceedings of the National Academy of Sciences, 116(16), 7905-7910. DOI:10.1073/ pnas. 1803456116

Galvis, G., \& Mojica, J.I. (2007). The Magdalena River freshwater fishes and fisheries. Aquatic Ecosystem Health \& Management, 10, 127-139.

Garcia, D.A.Z., Magalhães, A.L.B., Vitule, J.R.S., Casimiro, A.C.R., Lima-Junior, D.P., Cunico, A.M. ... Orsi, M.L. (2018). The same old mistakes in aquaculture: the newly-available striped catfish Pangasianodon hypophthalmus is on its way to putting Brazilian freshwater ecosystems at risk. Biodiversity and Conservation, 27(13), 3545-3558. DOI: 10.1007/ s10531-018-1603-1

GBIF.org. (18 December, 2019). GBIF Occurrence Download https://doi.org/10.15468/dl.dqn2xk

GBIF.org. (05 August, 2020a). GBIF Occurrence Download https://doi.org/10.15468/dl.29vk84

GBIF.org. (05 August, 2020b). GBIF Occurrence Download https://doi.org/10.15468/dl.59ceaw

GBIF.org. (05 August, 2020c). GBIF Occurrence Download https://doi.org/10.15468/dl.8neyf9

Gurevitch, J., \& Padilla, D.K. (2004). Are invasive species a major cause of extinctions? Trends in Ecology \& Evolution, 19(9), 470-474.
Gutiérrez, F.P., Lasso, C.A., Baptiste, M.P., SánchezDuarte, P., \& Díaz, A.M. (2012). VI. Catálogo de la biodiversidad acuática exótica y trasplantada en Colombia: moluscos, crustáceos, peces, anfibios, reptiles y aves. Serie Editorial Recursos Hidrobiológicos y Pesqueros Continentales de Colombia. Bogotá D.C., Colombia: Instituto de Investigación de los Recursos Biológicos Alexander von Humboldt $(\mathrm{IAvH})$.

Hijmans, R.J., van Etten, J., Cheng, J., Mattiuzzi, M., Sumner, M., Greenberg, J.A., ... Shortridge, A. (2015). Package "raster": geographic data analysis and modeling (Version 3.1-5, "R package"). Retrieved from https://cran.r-project.org/web/packages/raster/ raster.pdf

Hobbs, R.J. (2000). Invasive species in a changing world. Washington D.C., EE.UU.: Island Press.

Hulme, P.E., Bacher, S., Kenis, M., Klotz, S., Kühn, I., Minchin, D., ... Solarz, M.W. (2008). Grasping at the routes of biological invasions: a framework for integrating pathways into policy. Journal of Applied Ecology, 45(2), 403-414.

IAvH (Instituto de Investigación de Recursos Biológicos Alexander von Humboldt). (s.f.). Pez basa: seis años nadando con el enemigo. Instituto Humboldt. Recuperado de http://www.humboldt.org.co/en/noticias-2/ press/item/1044-nadando-con-el-enemigo

InvBasa UN. (2020). Ocurrencies of alien species registered by the InvBasa Platform. v1. Universidad Nacional de Colombia y Fundación Humedales. [Database]. Retrieved from https://ipt.biodiversidad. $\mathrm{co} / \mathrm{sib} /$ resource? $\mathrm{r}=$ invbasa-un

Islam, M.A., Uddin, M.H., Uddin, M.J., \& Shahjahan, M. (2019). Temperature changes influenced the growth performance and physiological functions of Thai pangas Pangasianodon hypophthalmus. Aquaculture Reports, 13, 100179. DOI: 10.1016/j. aqrep.2019.100179

Jaramillo, D.F. (2002). Introducción a la ciencia del suelo. Medellín, Colombia: Escuela de Geociencias y Medio Ambiente, Universidad Nacional de Colombia. Recuperado de https://repositorio.unal. edu.co/bitstream/handle/unal/70085/70060838.2002. pdf? sequence $=1 \&$ is Allowed $=\mathrm{y}$

Jiménez-Segura, L.F., Galvis-Vergara, G., Cala-Cala, P., García-Alzate, C., López-Casas, S., Ríos-Pulgarín, M., ... Álvarez-León, R. (2016). Freshwater fish faunas, habitats and conservation challenges in the Caribbean river basins of North-Western South America. Journal of Fish Biology, 89, 65-101. DOI: $10.1111 / \mathrm{jfb} .13018$

Jiménez-Segura, L.F., Gutierrez, F.P., Ajiaco-Martínez, R.E., \& Lasso, C.A. (2020a). Las Pesquerías Continentales en Colombia. En C. Baigún \& J. ValboJorgensen (Eds.), El estado y las Tendencias de las 
Pesquerías Continentales Artesanales de Meso y Surámerica. Manuscrito inédito, Circular de Pesca y Acuicultura, FAO.

Jiménez-Segura, L.F., Herrera-Pérez, J., Valencia-Rodríguez, D., Castaño-Tenorio, I., López-Casas, S., RíosPulgarín, M.I., ... Restrepo-Santamaría, D. (2020b). Ecología e historias de vida de los peces en la cuenca del río Magdalena, Colombia. En L. Jiménez-Segura, \& C. Lasso (Eds.), XIX. Peces de la cuenca del río Magdalena, Colombia: diversidad, conservación y uso sostenible (pp. 159-203). Bogotá D.C., Colombia: Instituto de Investigación de Recursos Biológicos Alexander von Humboldt. DOI: 10.21068/ A2020RRHHXIX

Jiménez-Segura, L.F., Palacio, J., \& Leite, R. (2010). River flooding and reproduction of migratory fish species in the Magdalena River basin, Colombia. Ecology of Freshwater Fish, 19(2), 178-186.

Jiménez-Segura, L.F., Palacio, J., \& López, R. (2009). Características biológicas del blanquillo (Sorubim cuspicaudus) Littmnann, Burr y Nass, 2000 y bagre rayado (Pseudoplatystoma magdaleniatum) Buitrago-Suárez y Burr, 2007 (Siluriformes: Pimelodidae) relacionadas con su reproducción en la cuenca media del Río Magdalena. Actualidades Biológicas, 31(90), 53-66.

Jiménez-Valverde, A., Peterson, A.T., Soberón, J., Overton, J.M., Aragón, P., \& Lobo, J.M. (2011). Use of niche models in invasive species risk assessments. Biological Invasions, 13(12), 2785-2797.

Lakra, W.S., \& Singh, A. (2010). Risk analysis and sustainability of Pangasianodon hypophthalmus culture in India. Aquaculture Asia, 15(1), 34-37.

Lasso, C., Escobar, M.D., Herrera, J., Castellanos, M.C., Valencia-Rodríguez, D., Campuzano, J., ... JiménezSegura, L. (2020). Peces introducidos en el río magdalena y cuencas vecinas, Colombia. En L. Jiménez-Segura, \& C.A. Lasso (Eds.), XIX. Peces de la cuenca del río Magdalena, Colombia: diversidad, conservación y uso sostenible (pp. 295-369). Bogotá, D.C., Colombia: Instituto de Investigación de Recursos Biológicos Alexander von Humboldt. DOI: 10.21068/A2020RRHHXIX

Lauzeral, C., Leprieur, F., Beauchard, O., Duron, Q., Oberdorff, T., \& Brosse, S. (2011). Identifying climatic niche shifts using coarse-grained occurrence data: A test with non-native freshwater fish. Global Ecology and Biogeography, 20(3), 407-414. DOI: 10.1111/j.1466-8238.2010.00611.x

Lehner, B., \& Grill, G. (2013). Global river hydrography and network routing: Baseline data and new approaches to study the world's large river systems. Hydrological Processes, 27(15), 2171-2186. DOI: 10.1002/hyp.9740
Liu, C., Comte, L., \& Olden, J.D. (2017). Heads you win, tails you lose: Life-history traits predict invasion and extinction risk of the world's freshwater fishes. Aquatic Conservation: Marine and Freshwater Ecosystems, 27(4), 773-779.

Liu, C., Wolter, C., Xian, W., \& Jeschke, J.M. (2020). Most invasive species largely conserve their climatic niche. Proceedings of the National Academy of Sciences, $117(38), 23643-23651$.

Lockwood, J.L., Hoopes, M.F., \& Marchetti, M.P. (2007). Invasion Ecology. West Sussex, UK: John Wiley \& Sons.

López-Casas, S., Jiménez-Segura, L.F., Agostinho, A.A., \& Pérez, C.M. (2016). Potamodromous migrations in the Magdalena River basin: bimodal reproductive patterns in neotropical rivers. Journal of Fish Biology, 89(1), 157-171. DOI:10.1111/jfb.12941

Maldonado-Ocampo, J.A., Ortega-Lara, A., Usma-Oviedo, J.S., Galvis-Vergara, G., Villa-Navarro, F.A., Vásquez-Gamboa, L., ... Ardila-Rodríguez, C. (2005). Peces de los Andes de Colombia. Guía de campo. Bogotá D.C., Colombia: Instituto de Investigación de Recursos Biológicos Alexander von Humboldt.

Mendoza-Alfaro, R., Luna-Peña, S., \& Arias-Gámez, A. (2013). Evaluación de riesgo por la introducción de especies de bagre asiático del género Pangasius para su cultivo en México. Ciudad de México, México: Comisión Nacional de Acuacultura y Pesca (CONAPESCA).

Mitra, A.K., Bandyopadhyay, P.K., Gong, Y., Goswami, M., \& Bhowmik, B. (2013). Description of two new species of ectoparasitic Trichodina Ehrenberg, 1830 (Ciliophora: Trichodinidae) from freshwater fishes in the river Ganges, India. Journal of Parasitic Diseases, 37(1), 35-41. DOI: 10.1007/s12639-012-0126-Z

Mojica, J.I., Usma, J.S., Álvarez-León, R., \& Lasso, C.A. (Eds.). (2012). Libro rojo de peces dulceacuícolas de Colombia 2012. Bogotá, D.C., Colombia: Instituto de Investigación de Recursos Biológicos Alexander von Humboldt, Instituto de Ciencias Naturales de la Universidad Nacional de Colombia, WWF Colombia y Universidad de Manizales.

Muscarella, R., Galante, P.J., Soley-Guardia, M., Boria, R.A., Kass, J.M., Uriarte, M., \& Anderson, R.P. (2014). ENMeval: An R package for conducting spatially independent evaluations and estimating optimal model complexity for Maxent ecological niche models. Methods in Ecology and Evolution, 5(11), 1198-1205. DOI: 10.1111/2041-210x.12261

Nori, J., \& Rojas-Soto, O. (2019). On the environmental background of aquatic organisms for ecological niche modeling: a call for caution. Aquatic Ecology, 53(4), 595-605. DOI: 10.1007/s10452-019-09711-6 
Owens, H.L., Campbell, L.P., Dornak, L.L., Saupe, E.E., Barve, N., Soberón, J., ... Peterson, A.T. (2013). Constraints on interpretation of ecological niche models by limited environmental ranges on calibration areas. Ecological Modelling, 263, 10-18. DOI: 10.1016/j.ecolmodel.2013.04.011

Pallewatta, N., Reaser, J.K., \& Gutierrez, A.T. (2003). Invasive Alien Species in South-Southeast Asia: National Reports and Directory of Resources. Global Invasive Species Programme, Cape Town, South Africa, 85-90.

Parra, J.L., Graham, C.C., \& Freile, J.F. (2004). Evaluating alternative data sets for ecological niche models of birds in the Andes. Ecography, 27(3), 350-360. DOI: 10.1111/j.0906-7590.2004.03822.x

Pearson, R.G., Raxworthy, C.J., Nakamura, M., \& Peterson, A.T. (2007). Predicting species distributions from small numbers of occurrence records: A test case using cryptic geckos in Madagascar. Journal of Biogeography, 34(1), 102-117. DOI: 10.1111/j.1365-2699.2006.01594.x

Peterson, A.T. (2003). Predicting the geography of 'species' invasions via ecological niche modeling. The Quarterly Review of Biology, 78(4), 419-433.

Peterson, A.T. (2006). Uses and Requirements of Ecological Niche Models and Related Distributional Models. Biodiversity Informatics, 3, 59-72. DOI: 10.17161/ bi.v3i0.29

Phillips, S.J., Anderson, R.P., \& Schapire, R.E. (2006). Modelling and analysis of the atmospheric nitrogen deposition in North Carolina. International Journal of Global Environmental Issues, 6(2-3), 231-252. DOI: $10.1016 /$ j.ecolmodel.2005.03.026

Phillips, S.J., \& Dudík, M. (2008). Modeling of species distributions with Maxent: new extensions and acomprehensive evaluation. Ecography, 31, 161-175. DOI: 10.1111/j.2007.0906-7590.05203.x

Phillips, S.J., Dudík, M., \& Schapire, R.E. (2004). A maximum entropy approach to species distribution modeling. Proceedings, Twenty-First International Conference on Machine Learning, ICML 2004, 655662. DOI: $10.1145 / 1015330.1015412$

QGIS.org. (2020). QGIS Geographic Information System. QGIS Association. (Version 3.16). Retrieved from https://qgis.org

R Core Team. (2014). R: A language and environment for statistical computing. R Foundation for Statistical Computing. Vienna, Austria. Retrieved from http:// www.r-project.org/\%0A

Raman, R.P., Mishra, A., Kumar, S., Sahay, S., Bhagat, M.N., \& Kumar, S. (2013). Introductions of Exotic Fish Species into Indian Waters: An overview of benefits, impacts, issues and management. In U.C.
Goswami (Ed.), Advances in Fish Research (pp. 1-14). Delhi, India: Narendra Publishing House.

Raxworthy, C.J., Ingram, C.M., Rabibisoa, N., \& Pearson, R.G. (2007). Applications of ecological niche modeling for species delimitation: A review and empirical evaluation using day geckos (Phelsuma) from Madagascar. Systematic Biology, 56(6), 907-923. DOI: 10.1080/10635150701775111

Raxworthy, C.J., Martinez-Meyer, E., Horning, N., Nussbaum, R.A., Schneider, G.E., Ortega-Huerta, M.A., \& Peterson, A.T. (2003). Predicting distributions of known and unknown reptile species in Madagascar. Nature, 426, 837-841. DOI: 10.1038/ nature 02205

Sato, M., Kawaguchi, Y., Nakajima, J., Mukai, T., Shimatani, Y., \& Onikura, N. (2010). A review of the research on introduced freshwater fishes: New perspectives, the need for research, and management implications. Landscape and Ecological Engineering, 6(1), 99-108. DOI: 10.1007/s11355-009-0086-3

SiB Colombia. (2020). Portal de Datos, Sistema de Información sobre Biodiversidad de Colombia [Base de datos]. Recuperado de https://datos.biodiversidad.co

Singh, A.K., \& Lakra, W.S. (2011). Risk and benefit assessment of alien fish species of the aquaculture and aquarium trade into India. Reviews in Aquaculture, 3(1), 3-18. DOI: 10.1111/j.1753-5131.2010.01039.x

Srivastava, V., Lafond, V., \& Griess, V.C. (2019). Species distribution models (SDM): Applications, benefits and challenges in invasive species management. CAB Reviews: Perspectives in Agriculture, Veterinary Science, Nutrition and Natural Resources, 14(20). DOI: 10.1079/PAVSNNR201914020

Tarkan, A.S., Yoğurtçuoğlu, B., Ekmekçi, F.G., Clarke, S.A., Wood, L.E., Vilizzi, L., \& Copp, G. (2020). First application in Turkey of the European Nonnative Species in Aquaculture Risk Analysis Scheme to evaluate the farmed non-native fish, striped catfish Pangasianodon hypophthalmus. Fisheries Management and Ecology, 27(2), 123-131. DOI: 10.1111/ fme. 12387

The Nature Conservancy, Fundación Alma, Fundación Humedales, \& AUNAP. (2016). Estado de las planicies inundables y el recurso pesquero en la Macrocuenca Magdalena-Cauca y propuesta para su manejo integrado. Bogotá, Colombia. Recuperado de https://nanopdf.com/download/estado-de-las-planicies-inundables-y-el-recurso-pesquero-en-la_pdf

Valderrama, M., Mojica, J.I., Villalba, A., \& Avila, F. (2016). Presencia del pez basa, Pangasianodon hypophthalmus (Sauvage, 1878) (Siluriformes: Pangasiidae), en la cuenca del río Magdalena, Colombia. Biota Colombiana, 7(2), 304. DOI: 10.21068/c2016. v17n02a13 
Valencia-Rodríguez, D., Jiménez-Segura, L., Rogéliz, C.A., \& Parra, J.L. (2021) Ecological niche modeling as an effective tool to predict the distribution of freshwater organisms: The case of the Sabaleta Brycon henni (Eigenmann, 1913). PLoS ONE, 16(3): e0247876. DOI: 10.1371/journal.pone.0247876

van Kleunen, M., Schlaepfer, D.R., Glaettli, M., \& Fischer, M. (2011). Preadapted for invasiveness: do species traits or their plastic response to shading differ between invasive and non-invasive plant species in their native range? Journal of Biogeography, 38(7), 1294-1304.

Van Zalinge, N., Lieng, S., Ngor, P.B., Heng, K., \& ValboJørgensen, J. (2002). Status of the Mekong Pangasianodon hypophthalmus resources, with special reference to the stock shared between Cambodia and Viet Nam. MRC Technical Paper, 1, 1-29.

Warren, D.L., Glor, R.E., \& Turelli, M. (2008). Environmental niche equivalency versus conservatism: Quantitative approaches to niche evolution. Evolution, 62(11), 2868-2883. DOI: 10.1111/j.1558-5646.2008.00482.x

Warren, D.L., Glor, R.E., \& Turelli, M. (2010). ENMTools: A toolbox for comparative studies of environmental niche models. Ecography, 33(3), 607-611 DOI: 10.1111/j.1600-0587.2009.06142.x

West, A.M., Kumar, S., Brown, C.S., Stohlgren, T.J., \& Bromberg, J. (2016). Field validation of an invasive species Maxent model. Ecological Informatics, 36, 126-134. DOI: 10.1016/j.ecoinf.2016.11.001

Wiens, J.J., \& Graham, C.H. (2005). Niche conservatism: Integrating evolution, ecology, and conservation biology. Annual Review of Ecology, Evolution, and Systematics, 36, 519-539. DOI: 10.1146/annurev. ecolsys.36.102803.095431

Wisz, M.S., Hijmans, R.J., Li, J., Peterson, A.T., Graham, C.H., Guisan, A., \& NCEAS Predicting Species Distributions Working Group. (2008). Effects of sample size on the performance of species distribution models. Diversity and Distributions, 14(5), 763-773. DOI: $10.1111 / \mathrm{j} .1472-4642.2008 .00482 . x$

Yiwen, Z., Bi Wei, L., \& Darren, C.J. (2016). Novel methods to select environmental variables in MaxEnt: A case study using invasive crayfish. Ecological Modelling, 341, 5-13. DOI: 10.1016/j.ecolmodel.2016.09.019 